\title{
RAPID TRANSFORMATION OF ORCHID FLORAS
}

\author{
JAMES D. ACKERMAN \\ Department of Biology and Center for Applied Tropical Ecology and Conservation, \\ University of Puerto Rico, PO Box 23360, San Juan, PR 00931-3360, U.S.A. \\ ackerman.upr@gmail.com
}

\begin{abstract}
What does the future hold for the Orchidaceae? Historically the family has been quite plastic and responsive to large-scale habitat transformations, perhaps none so dramatic as the changes experienced during the formation of the cordilleras of the Northern Andes and lower Central America. Coupled with the backdrop of global fluctuations in climate, the rapid rise of these mountains over the last 0.5-2 $\mathrm{M}$ years have fragmented habitats and changed climate locally. These mountains are one of the most biologically diverse regions of the planet and may have served as a species pump for the Caribbean and other regions of Central and South America. The development of such diversity occurred over a scale of tens of millions of years to perhaps just a few thousand. While the same processes of the past are likely operational now, the current rate of habitat change may be unprecedented outside asteroid or major meteor impacts as global climate change accelerates, humanaltered landscapes spread, and shifts occur in land use. We expect the structure and composition of orchid floras to change as populations respond evolutionarily through adaptation, extinctions and immigrations. Certainly the total destruction of a habitat, whether caused by volcanic eruptions or strip mining, is sure to have dire consequences but resiliency may occur if refugia serve as seed sources for colonization in the event of habitat recovery. As most orchids occupy ephemeral habitats or at least substrates, their natural population behavior likely entails cycles of local colonization and extinction as metapopulations. Another component of change is the increasing number of orchids that have become naturalized after human assisted dispersal (intentional or not). These alien orchids have overcome constraints imposed by pollination and mycorrhizal requirements. Will natural or human-assisted range expansions overcome extinction losses? Will they be among those that become the genetic material for a new wave of adaptive radiations? Much depends on population variation, patterns of gene flow, and rates of change. The Orchidaceae have had a history of ecological resiliency and evolutionary flexibility, which provides some degree of assurance. But this is no excuse for complacency since without some form of intervention the pace of change underway may be more than what orchid populations can overcome.
\end{abstract}

KEY WORDS: Orchidaceae, conservation, resiliency, floristic change, forest recovery

The orchid mystique is alive and well. The bizarre flowers, weird pollination mechanisms, and rarity of many species have captured the attention of enthusiasts and academics for nearly two centuries. Population declines of marquee species have been obvious due to over-collecting and habitat degradation (e.g., Miranda 1990, Cribb 1998, Soto Arenas et al. 2007). Consequently, orchids are frequent if not prominent occupants of endangered species lists and all 28,000-plus species of the family (Govaerts et al. 2010) have been placed on either appendix I or II of the Convention on International Trade in Endangered Species (CITES). Moreover, several books have focused on orchid conservation (e.g., IUCN/SSC Orchid Specialist Group 1996, Koopowitz 2001, Dixon et al. 2003). Are these symptoms of a dire outlook for the family? Will orchids survive rapid climate and land use changes?

To address these questions, I look at how the family has responded to disturbances through history. I emphasize processes related to diversification and population biology of the family in the northern Andes

* This contribution was prepared as part of the special edition of LANKESTERIANA that is dedicated to the commemoration of Lankester Botanical Garden's 40th anniversary. 
and the cordilleras of Panama and Costa Rica, two regions of extraordinary species diversity (Dressler 1981, Myers et al. 2000, Bogarín et al. 2013).

Early patterns of diversification. - Variance in age estimates for the Orchidaceae has been rather substantial (Arditti 1992, Gustafsson et al. 2010), but our current data indicate that the family is rather old. Initial age estimates of Ramírez et al. (2007) and Gustafsson et al. (2010) based on molecular clock calculations have been further refined by Guo et al. (2012) who have found that the most recent common ancestor of the Orchidaceae existed roughly 80-90 Ma, in the Late Cretaceous. From their analyses, most, if not all of the five current subfamilies diverged prior to the global disturbance and mass extinctions associated with the Cretaceous/Paleogene (K-Pg) boundary. This boundary, likely instigated by an asteroid impact at the edge of the present day Yucatan Peninsula (Morgan et al. 2008), not only caused extinctions of many forms of life, most famously the non-avian dinosaurs, but also opened doors to the evolutionary theater for diversification of other forms, including mammals and flowering plants. Beyond the K-Pg boundary, two clades represented by subfamilies Orchidoideae and Epidendroideae underwent evolutionary diversification that accounts for most of the species diversity of the orchid family as it is known today. Many clades from those subfamilies diverged just 15-20 Ma BP in the early Miocene (Ramírez et al. 2007, Guo et al. 2012). Of course, not all species that evolved during these years of diversification have survived. Extinction is a natural process and does not need the helping hand of humans. Nevertheless, we may assume that there has been an overall net gain in species. So, although the family's origins are rather old and some clades are relatively species-poor, the Orchidaceae as a whole is hardly relictual or static.

Recent evolutionary diversification. - While broadscale orchid diversification events cannot be easily linked to large-scale disturbances, tectonic dynamics most assuredly fostered the diversification of orchids and other families (Hughes \& Eastwood 2006). A good example is the recent rise of lower Central America and northern Andean cordilleras over the last 0.5$10 \mathrm{Ma}$ (Dodson 2003, Kirby 2007, Karremans et al.
2013, Cascante-Marín \& Nivia-Ruíz 2013). The result has been rapid diversification and fragmentation of habitats, which become isolated not only by valleys and ridges within mountain ranges, but also by intervening hotter and drier lowlands between them (Kirby 2011). Not surprisingly, topographic diversity is strongly associated with orchid diversity, even exceeding area as a factor linked to species richness (Dodson 2003, Ackerman et al. 2007). This relationship is well illustrated by the Maxillariinae of Panama and Costa Rica. Kirby (2011) found that widespread species of the subtribe tend to occupy lowlands whereas the narrow endemics and more derived species are those occupying the cooler, wetter montane slopes and valleys. While we expect such barriers to substantially limit gene flow, we still need to reconcile metaanalysis of $\mathrm{F}_{\mathrm{st}}\left(\right.$ or $\left.\mathrm{G}_{\mathrm{st}}\right)$ statistics that indicate high levels of gene flow among orchid populations (Phillips et al. 2012). But if natural selection is intense enough and sustained, then selection could overcome any homogenizing effect of occasional input from longdistance dispersal, allowing for local adaptation and diversification. Of course such population genetic data are only consistent with high levels of gene flow. Alternatively, it may also reflect only a relatively recent colonization event with little or no subsequent gene flow (Tremblay et al. 2005). Changes in neutral alleles would be mutation-dependent and divergence from parental populations may take a long time to occur. On the other hand, frequencies of alleles under selection may change rapidly as has been observed in other organisms (Losos 2014) and such differences would be missed by population genetic data based on assessment of neutral alleles.

While rapid rise of mountain ranges are clearly associated with the evolution of biological diversity, it is not a prerequisite for rapid orchid speciation. Gustafsson et al. (2010) found that much of the extant diversity of the orchid genus Hoffmannseggella in the geologically ancient eastern mountains of Brazil diverged since the Pliocene $(<2.5 \mathrm{Ma})$. During this same period significant fluctuations in moisture availability occurred (Auler \& Smart 2001, Ledru et al. 2005), perhaps climatically fragmenting the landscape and affecting gene flow among populations with consequences akin to abrupt mountain building. 
The driver for the remarkable evolutionary diversification of this family is likely tied to the process of pollination (van der Pijl \& Dodson 1966, Stebbins 1984, Nilsson 1992, Chase 2001, Papadopulos et al. 2013), though the family also shows a broad range of physiological and vegetative adaptations (Dressler 1981, Benzing 1986, Arditti 1992), and we are only just beginning to understand the role of mycorrhizal associations in orchid evolution (e.g., Otero \& Flanagan 2006; Motomura et al. 2010, Martos et al. 2012). The plethora of pollination mechanisms, some rather fantastic, and the exploitation of a broad spectrum of pollinators suggest that the post K-Pg diversification of insects, particularly Diptera, Lepidoptera and Hymenoptera, is closely tied to the evolutionary potential of the Orchidaceae, although not necessarily in a co-evolutionary dance (Ackerman 1983a, Ramírez et al. 2011, see also Schiestl \& Dötterl 2012). Species with little sequence divergence may have arisen rapidly via exploitation of existing pollinator diversity. This is perhaps best exemplified by genera that employ sexual deception (e.g., Lepanthes R.Br., Ophrys L., Telipogon Kunth, Chiloglottis R.Br.; Blanco \& Barboza 2007, Bateman et al. 2003, Neubig et al. 2012, Peakall et al. 2010).

Thus, the family is rather old, but much diversification is recent, geologically speaking. It appears that orchids are adept at responding evolutionarily to change occurring over millions of years to perhaps just a few thousand. Gentry and Dodson (1987) even suggested that speciation may occur over just a few decades, an idea with virtually no support, but it had planted the seed for breaking the shackles of gradualism in orchids (Tremblay et al. 2005).

Habitat changes over ecological time. - Change is ubiquitous and has always been that way, but the current rate of habitat change may be unprecedented outside asteroid or major meteor impacts as global climate change accelerates, human-altered landscapes spread, and shifts occur in land use. Habitat destruction is the foremost threat to orchids (IUCN/SSC Orchid Specialist Group 1996), so the question is whether the family as a whole has the resiliency to withstand the onslaught of change.

One obvious way in which orchids may respond to change is extinction. But considering the size of the family and the presumably high frequency of rare species, the number of known extinctions is quite low (IUCN/SSC Orchid Specialist Group 1996). This is counter-intuitive since rare species should be more vulnerable to habitat destruction. One explanation may be a function of the lack of human effort to document extinctions and the other may be a function of the biology of orchids. The former is difficult to verify so I will explore the latter.

Rapid changes in habitats have occurred throughout history and some dramatic events that have occurred recently will serve as examples. Disturbances that have caused population extinctions may occur at every scale. When a host tree sheds twigs and branches or dies entirely, so do its epiphytes. In 1989, a strong hurricane passed over Puerto Rico and through a relatively mature forest for the first time in many decades. Nearly half the trees fell or snapped off and those that withstood the winds had all their orchid epiphytes stripped away (Migenis \& Ackerman 1993). Volcanic eruptions can be even more destructive than hurricanes. Krakatau is the best known example of nearly instant devastation when it exploded in 1883, destroying itself and nearby islands, covering extensive areas with debris, generating severe earthquakes and tsunamis, and by the infusion of sulfur dioxide in the stratosphere, cooling the planet for years afterwards (Thornton 1997). In a somewhat older violent eruption, Tungurahua II of the Ecuadorian Andes literally blew its top approximately 3000 years ago devastating the landscape with massive amounts of rubble and thick layers of ash (Hall et al. 1999), presumably creating lifeless moonscapes as were observed in the Krakatau explosion. Despite such ever-present yet rare natural threats to habitat stability, the most pressing issues for orchid conservation are the devastating consequences of human activities.

Like natural disturbances, those caused by man can be at every scale up to regional or even global. At very local levels human activities such as trampling can have both indirect and direct effects on orchids (Light \& MacConaill 2007; Ballantyne \& Pickering 2013). In the orchid-rich tropics, slash and burn agriculture created forest gaps, but much of that has been replaced by increasingly larger scale agriculture to the point of having farms measured in square kilometers rather than in hectares where topography and environmental 
conditions permit it. Perhaps the greatest changes will come from accelerating (anthropogenic or not) climate changes whose effects may be seen even within a span of a few years to decades (Allen \& Breshears 1998, Kelly \& Goulden 2008). Whether it is the warming trend with accompanying drier or wetter conditions (depending on region), or the increasing severity of weather, we have already begun to see changes and developing consequences, and cloud forests, where orchids thrive, seem to be highly susceptible (Pounds et al. 1999, Parmesan 2006, Gradstein 2008).

Recovery. - I expect that natural disturbances beget natural recoveries. Small-scale disturbances are common and most orchids likely have the capacity for recovery. After all, epiphytic orchids must constantly be on the move as bark and branches are shed and trees die, so orchid population dynamics may resemble metapopulation behavior (Ackerman 1983b, Tremblay et al. 2006). Certainly one expects that after a hurricane, orchids should be resilient since they have been for millions of years (Ackerman \& Moya 1996, Mújica et al. 2013). Recovery can be relatively rapid, even after volcanic eruptions. Among the first vascular plants to colonize the remnants of Krakatau were orchids, and now the number of species continues to accumulate (63 species after 115 years) as the vegetation structure becomes more complex and more hospitable for epiphytes (Partomihardjo 2003). As for the Tungurahua II eruption in the Ecuadorian Andes, the mountain has rebuilt to $50 \%$ of its former size (Tungurahua III, Hall et al. 1999). The slopes have become re-vegetated, the orchid flora changes during this process, and colonizing species gradually disappear as others replace them. The overall effect is the mountain becomes orchid-rich once again, which includes a number of species that presumably occur nowhere else, with the implication that they may have evolved in just a few thousand years (Dodson 2003). The case of this volcano is not likely unusual. Ecuador has over 200 volcanoes and according to naturalist Alex Hirtz, approximately $20 \%$ of the orchid flora on each is endemic to that volcano (http://alexanderhirtz. com/orchid).

Recovery of orchid floras from anthropogenic disturbances is currently not well characterized, but will soon be with us on a grand scale. While deforestation still continues in some regions of the world at an alarming rate, there has been a reversal in the trend, mostly in shrubby arid zones and mountainous regions where modern large scale, mechanized agriculture has not been practical (Aide et al. 2012). A general reforestation trend has been occurring in both temperate and tropical regions such as Europe, USA, Puerto Rico, Dominican Republic, Costa Rica, Ecuador and Colombia, a phenomenon often associated with abandonment of small rural farms as a consequence of industrialization, economic growth, and sometimes armed conflicts (Sánchez-Cuervo et al. 2012). I expect that orchid population recovery should follow provided the existence of nearby refugia that may serve as propagule sources.

Once forests are restored or recover from human disturbances, will orchid floristic composition return to past conditions? Considering the forests themselves may not return to past structure and composition (e.g., Thompson et al. 2002, Lugo 2004), we may assume the same for orchid floras as change occurs for both ecological and evolutionary reasons. The extensive forested regions of Mexico, Guatemala, and Belize were once thought to be pristine, but we know now that they were deforested and extensively cultivated by Mayans, which was severe enough to create several episodes of significant erosion (Beach et al. 2006). The forests are now orchid-rich, but we will never know whether they have lost or even gained species from pre-Maya times. In a relatively well-documented case, approximately $95 \%$ of the island of Puerto Rico was deforested and converted to farmlands by the 1940s (Roberts 1942, Wadsworth 1950). This was followed by a change from an agrarian to an industrial-based society accompanied by human migration from rural areas to cities. The abandoned farmland formed secondary forests composed of a mix between native and non-native trees. Despite high human population densities, over $40 \%$ of the island now has forest cover (Grau et al. 2003). How did the orchid flora fair? Very few of the reported species for the island have been lost, and most of those that have not been seen for decades were known from only a single specimen, if any at all (Ackerman 1996). Small refugia were likely critical for floristic recovery as has been proposed for vegetation transition on other islands (de Boer et al. 2013). But where disturbance had been severely 
habitat altering, recovery for some orchid species has yet to occur, even after ecosystem recovery (Bergman et al. 2006). Shifts in the orchid flora over the last few decades have been dramatic. Large populations of twig epiphytes were once commonly encountered but now have become uncommon as forest recovery has progressed, shading out both the orchids and their hosts. Moreover, non-native orchids have taken hold in many parts of the island, currently making up about $7 \%$ of the orchid flora (Ackerman 2007).

Conclusions. - Orchids throughout their history seem to have done well in face of climatic change caused by shifting continents, mountain building, fluctuating sea levels and temperatures. All these phenomena occur today but the rate of change seems to be occurring faster than the detectable past. Nature reserves are of course as susceptible to climate change as anywhere else. Liu et al. (2010) estimate that populations of at least $15 \%$ of the orchid species in a diverse region of southwestern China will be threatened with extinction over the next two centuries given projected climate changes. We already see a drying trend in some cloud forests of the world, including Costa Rica, raising real concerns for those species such as the hundreds of Neotropical Lepanthes that depend on cool, wet conditions (Nadkarni \& Solano 2002; Olaya-Arenas et al. 2011). How orchids respond remains to be seen but it seems certain that the floras at any given site will not be the same as before.

Orchids as a group show evolutionary flexibility whereby diversification in the family is often related to habitat complexity and fragmentation. Orchids also show ecological resiliency with the capacity for recolonization after habitat destruction and recovery. For particular orchid species, the realization of these capacities likely depends upon dispersal from refugia (large or small), the severity of disturbance, effects of invasive species, and the natural history of the individual orchid species. Should refugia cease to exist, or habitat restoration becomes constrained, then recovery of orchid floras will not only be lethargic, but the floristic outcome may only superficially resemble the species composition and relative abundance patterns of the past. And whether changes are local or global, we can only hope that the ability of orchids to adapt or migrate will keep pace.
Coda. - There are few botanical institutions in tropical regions of high orchid diversity. Over a relatively short period of time, Lankester Botanical Garden has become one of those that have had a significant role in tropical orchid systematics and conservation, effectively promoting in-house research; facilitating studies at other institutions through collaborations and the development of the online resource, EPIDENDRA; and fostering communication among botanists by publishing Lankesteriana and sponsoring scientific meetings. Indeed, I have had many influences in the development of the ideas contained herein, but articles in Lankesteriana did as much as any to help coalesce them.

AcKNOWLEDGEMENTS. I thank Stephen Kirby and Raymond Tremblay for fruitful discussions over the years that helped solidify some ideas contained here, though any blame falls squarely on my shoulders. I delivered a version of this essay at IV Andean Orchid Conservation Conference (Guayaquil, Ecuador, 2012), and I thank the organizers, especially Alec Pridgeon and José Portilla Andrade, for facilitating my participation. Further financial support was provided by CREST-CATEC (Elvira Cuevas, project director, National Science Foundation, USA, HRD-0734826) for which I am grateful.

\section{Literature Cited}

Ackerman, J.D. 1983a. Specificity and mutual dependency of the orchid-euglossine bee interaction. Biol. J. Linn. Soc. 20: 301-314.

Ackerman, J.D. 1983b. On the evidence for a primitively epiphytic habit in orchids. Syst. Bot. 8: 474-477.

Ackerman, J.D. 1996. Caribbean Islands. Pages 59-61 in IUCN/SSC Orchid Specialist Group. Orchids - status survey and conservation action plan. IUCN, Gland Switzerland and Cambridge, UK

Ackerman, J.D. 2007. Invasive orchids: weeds we hate to love? Lankesteriana 7: 19-21.

Ackerman, J.D. \& E.J. Meléndez-Ackerman. 2008. Orquídeas. Pages 189-246 in R. L. Joglar, ed. Biodiversidad de Puerto Rico: Agustín Stahl, Flora, Hongos. Serie de Historia Natural de Puerto Rico. La Editorial Universidad de Puerto Rico, San Juan.

Ackerman, J.D. \& S. Moya. 1996. Hurricane aftermath: resiliency of an orchid-pollinator interaction in Puerto Rico. Carib. J. Sci. 32: 369-374.

Ackerman, J.D., J.C. Trejo Torres \& Y. Crespo Chuy. 2007. 
Orchids of the West Indies: predictability of diversity and endemism. J. Biogeogr. 34: 779-786.

Aide, T.M., M.L. Clark, H.R. Grau, D. López-Carr, M.A. Levy, D. Redo, M. Bonilla-Moheno, G. Riner, M.J. Andrade-Nuñez \& M. Muñiz. 2013. Deforestation and reforestation of Latin America and the Caribbean (2001-2010). Biotropica 45: 262-271.

Allen, C.D. \& D.D. Breshears. 1998. Drought-induced shift of a forest-woodland ecotone: rapid landscape response to climate variation. Proc. Nat. Acad. Sci. (USA) 95: 14839-14842.

Arditti, J. 1992. Fundamentals of orchid biology. John Wiley \& Sons, New York.

Auler, A.S. \& P.L. Smart. 2001. Late quaternary paleoclimate in semiarid northeastern Brazil from U-series dating of travertine and water-table speleothems. Quatern. Res. 55: 159-167.

Ballantyne, M. \& C. Pickering. 2012. Ecotourism as a threatening process for wild orchids. J. Ecotourism 11: 34-47.

Bateman, R.M., P.M. Hollingsworth, J. Preston, Y.-B. Luo, A.M. Pridgeon \& M.W. Chase. 2003. Molecular phylogenetics and evolution of Orchidinae and selected Habenariinae (Orchidaceae). Bot. J. Linn. Soc. 142: $1-40$.

Beach, T., N. Dunning, S. Luzzadder-Bech, D.E. Cook \& J. Lohse. 2006. Impacts of the ancient Maya on soils and soil erosion in the central Maya Lowlands. Catena 65: 166-178.

Benzing, D.H. 1986. The genesis of orchid diversity: emphasis on floral biology leads to misconceptions. Lindleyana 1: 73-89.

Bergman, E., J.D. Ackerman, J. Thompson \& J.K. Zimmerman. 2006. Land use history affects the distribution of the saprophytic orchid Wullschlaegelia calcarata in Puerto Rico. Biotropica 38: 492-499.

Blanco, M.A. \& G. Barboza. 2007. Pseudocopulation pollination in Lepanthes (Orchidaceae: Pleurothallidinae). Ann. Bot. 95: 763-772.

Bogarín, D., F. Pupulin, C. Arrocha \& J. Warner. 2013. Orchids without borders: studying the hotspot of Costa Rica and Panama. Lankesteriana 13: 13-26.

Cascante-Marín, A. \& A. Nivia-Ruíz. 2013. Neotropical flowering epiphyte diversity: local composition and geographic affinities. Biodivers. Conserv. 22: 113-125.

Chase, M.W. 2001. Origin and biogeography of Orchidaceae. Pages 1-5. In A. Pridgeon, P. Cribb \& F. Rasmussen, eds. Genera Orchidacearum. Vol. 2. Oxford University Press, Oxford.

Cribb, P. 1998. The genus Paphiopedilum. $2^{\text {nd }}$ edition. Natural History Publications (Borneo), Kota Kinabalu, Malaysia.

De Boer, E.J., H. Hooghiemstra, F.B. Vincent Florens,
C. Baider, S. Engels, V. Dakos, M. Blaauw \& K.D. Bennett. 2013. Rapid succession of plant associations on the small oceanic island of Mauritius at the onset of the Holocene. Quatern. Sci. Rev. 68: 114-125.

Dixon, K.W., S.P. Kell, R.L. Barrett \& P.J. Cribb, eds. 2003. Orchid conservation. Natural History Publications (Borneo), Kota Kinabalu, Malaysia.

Dodson, C.H. 2003. Why are there so many orchid species? Lankesteriana "No. 7" 3(2): 99-103.

Dressler, R.L. 1981. The orchids: natural history and classification. Harvard University Press, Cambridge, MA.

Gentry, A.H. \& C.H. Dodson. 1987. Diversity and biogeography of neotropical vascular epiphytes. Ann. Missouri Bot. Gard.74: 205-233.

Govaerts, R., K. Kratochvil, G. Gerlach, G. Carr, P. Alrich, A.M. Pridgeon, J. Pfahl, M.A. Campacci, D. Holland Baptista, H. Tigges, J. Shaw, P. Cribb, A. George, K. Kreuz \& J. Wood. 2010. World Checklist of Orchidaceae. Facilitated by the Royal Botanic Gardens, Kew. http://www.kew.org/wcsp/monocots/ accessed 24 June 2010.

Gradstein, S.R. 2008. Epiphytes of tropical montane forests - impact of deforestation and climate change. Pages 5165. In S.R. Gradstein, J. Homeier \& D. Gansert, eds. The tropical mountain forest - patterns and processes in a biodiversity hotspot. Universitätverlag Göttingen.

Grau, H.R., T.M. Aide, J.K. Zimmerman, J.R. Thomlinson, E. Helmer and X. Zou. 2003. The ecological consequences of socioeconomic and land-use changes in postagriculture Puerto Rico. Bioscience 53: 11591168.

Guo, Y.-Y., Y.-B. Luo, Z.-J. Liu \& X.-Q. Wang. 2012. Evolution and biogeography of the slipper orchids: Eocene vicariance of the conduplicate genera in the Old and New World tropics. PLoS ONE 7: e38788. doi:10.1371/journal.pone.0038788

Gustafsson, A.L., C.F. Verola \& A. Antonelli. 2010. Reassessing the temporal evolution of orchids with new fossils and a Bayesian relaxed clock, with implications for the diversification of the rare South American genus Hoffmannseggella (Orchidaceae:Epidendroideae). BMC Evol. Biol. 10: 177. doi10.1186/1471-2148-10177

Hall, M.L., C. Robin, B. Beate, P. Mothes \& M. Monzier. 1999. Tungurahua Volcano, Ecuador: structure, eruptive history and hazards. J. Volcanology Geothermal Res. 91: 1-21.

Hughes, C. \& R. Eastwood. 2006. Island radiation on a continental scale: Exceptional rates of plant diversification after uplift of the Andes. Proc. Nat. Acad. Sci. USA 103: 10334-10339.

IUCN/SSC Orchid Specialist Group. 1996. Orchids - status 
survey and conservation action plan. IUCN, Gland Switzerland and Cambridge, UK

Karremans, A.P., F.T. Bakker, F. Pupulin, R. Solano-Gómez \& M.J.M. Smulders. 2013. Phylogenetics of Stelis and closely related genera (Orchidaceae: Pleurothallidinae). Pl. Syst. Evol. 299: 151-176. DOI 10.1007/s00606-0120712-7

Kelly, A.E. \& M.L. Goulden. 2008. Rapid shifts in plant distribution with recent climate change. Proc. Nat. Acad. Sci. USA 105:11823-11826.

Kirby, S.H. 2007. Geological processes and orchid biogeography with applications to southeast Central America. Lankesteriana 7: 53-55.

Kirby, S.H. 2011. Active mountain building and the distribution of "core" Maxillariinae species in tropical Mexico and Central America. Lankesteriana 11: 275291.

Koopowitz, H. 2001. Orchids and their conservation. Timber, Press, Portland, Oregon.

Ledru, M.-P., F.W. Cruz Jr., C. Riccomini, I. Karmann \& L. Martin. 2005. Paleoclimate changes during the last $100,000 \mathrm{yr}$ from a record in the Brazilian Atlantic rainforest region and interhemispheric comparison. Quatern. Res. 64: 444-450.

Light, M.H.S. \& M. MacConaill. 2007. Effect of trampling on a terrestrial orchid environment. Lankesteriana 7 : 294-298.

Liu, H., C.-L. Feng, Y.-B. Luo, B.-S. Chen, Z.-S. Wang \& H.-Y. Gu. 2010. Potential challenges of climate change to orchid conservation in a wild orchid hotspot in Southwestern China. Bot. Rev.76: 174-192.

Losos, J.B. 2014. What Darwin got wrong. Chron. Higher Ed. http://chronicle.com/article/What-Darwin-Got-Wro ng/144021/?key=TGxzdFc9YXRHZH8yYTtHYW4D O3I5ZRh1NX8ZYn9wb19QFw\%3D\%3D

Lugo, A.E. 2004. The outcome of alien tree invasions in Puerto Rico. Frontiers Ecol. Environ. 2: 265-273.

Martos, F., F. Munoz, T. Pailler, I. Kottke, C. Gonneau \& M.A. Selosse. 2012. The role of epiphytism in architecture and evolutionary constraint within mycorrhizal networks of tropical orchids. Mol. Ecol. 21: 5098-5109.

Migenis, L.E. \& J.D. Ackerman. 1993. Orchid-phorophyte relationships in a forest watershed in Puerto Rico. J. Trop. Ecol. 9: 231-240.

Miranda, F.E. 1990. Brazilian Laelias - part III: section Parviflorae. Amer. Orchid Soc. Bull. 59: 462-472.

Morgan, J., C. Lana, A. Kearsley, B. Coles, C. Belcher, S. Montanari, E. Díaz-Martínez, A. Barbosa \& V. Neumann. 2006. Analyses of shocked quartz at the global K-P boundary indicate an origin from a single, high-angle, oblique impact at Chicxulub. Earth and Planetary Sci. Lett. 251: 264-279.

Motomura, H., M.-A. Selosse, F. Martos A. Kagawa \&
T. Yukawa. 2010. Mycoheterotrophy evolved from mixotrophic ancestors: evidence in Cymbidium (Orchidaceae). Ann. Bot. 106: 573-581.

Mújica, E., J. Raventos, E. González \& A. Bonet. 2013. Long-term hurricane effects on populations of two epiphytic orchid species from Guanahacabibes Peninsula, Cuba. Lankesteriana 13: 47-55.

Myers, N., R.A. Mittermeter, C.G. Mittermeter, G.A.B. da Fonseca \& J. Kent. 2000. Biodiversity hotspots for conservation priorities. Nature 403: 853-858.

Nadkarni, N.M. \& R. Solano. Potential effects of climate change on canopy communities in a tropical cloud forest: an experimental approach. Oecologia 131: 580-586.

Neubig, K.M., W.M. Whitten, N.H. Williams, M.A. Blanco, L. Endara, J.G. Burleigh, K. Silvera, J.C. Cushman \& M.W. Chase. 2012. Generic recircumscriptions of Oncidiinae (Orchidaceae: Cymbidieae) based on maximum likelihood analysis of combined DNA datasets. Bot. J. Linn. Soc. 168: 117-146.

Nilsson, L.A. 1992. Orchid pollination biology. Trends Ecol. Evol. 7: 255-259.

Olaya-Arenas, P., E.J. Meléndez-Ackerman, M.E. Pérez \& R. Tremblay. 2011. Demographic response by a small epiphytic orchid. Amer. J. Bot. 98: 2040-2048.

Otero, J.T. \& N.S. Flanagan. 2006. Orchid diversity beyond deception. Trends Ecol. Evol. 21: 64-65.

Papadopulos, A.S.T., M.P. Powell, F. Pupulin, J. Warner, J.A. Hawkins, N. Salamin, L. Chittka, N.H. Williams, W.M. Whitten, D. Loader, L.M. Valente, M.W. Chase \& V. Savolainen. 2013. Convergent evolution of floral signals underlies the success of Neotropical orchids. Proc. Roy. Soc. B 280: 20130960. http://dx.doi. org/10.1098/rspb.2013.0960

Parmesan, C. 2006. Ecological and evolutionary responses to recent climate change. Ann. Rev. Ecol. Evol. Syst. 37: 637-669.

Partomihardjo, T. 2003. Colonisation of orchids on the Krakatau Islands. Teleopea 10:299-310.

Peakall, R., D. Ebert, J. Poldy, R.A. Barrow, W. Francke, C.C. Bower \& F.P. Schiestl. 2010. Pollinator specificity, floral odour chemistry and phylogeny of Australian sexually deceptive orchids: implications for pollinatordriven speciation. New Phytol. 188: 437-450.

Phillips, R.D., K.W. Dixon \& R. Peakall. 2012. Low population genetic differentiation in the Orchidaceae: implications for the diversification of the family. Mol. Ecol. 21: 5208-5220.

Pounds, J.A., M.P L. Fogden \& J H. Campbell. 1999. Biological response to climate change on a tropical mountain. Nature 398: 611-614.

Ramírez, S.R., B. Gravendeel, R.B. Singer, C.R. Marshall \& N.E. Pierce. 2007. Dating the origin of the Orchidaceae from a fossil orchid with its pollinator. Nature 448: 
1042-1045. Doi10.1038/nature06039

Ramírez, S.R., T. Else, M.K. Fujiwara, G. Gerlach, B. Goldman-Huertas, N.D. Tsutsui \& N.E. Pierce. 2011. Asynchronous diversification in a specialized plantpollinator mutualism. Science 333: 1742-1746. doi: 10.1126/science. 1209175

Roberts, R.C. 1942. Soil survey of Puerto Rico. Washington DC: U.S. Printing Office. USDA Series 1936., No. 8.

Sánchez-Cuervo, A.M., T.M. Aide, M.L. Clark \& A. Etter. 2012. Land cover change in Colombia: surprising forest recovery trends between 2001 and 2010. PLoS One 8: e43943. doi:10.1371/journal.pone.0043943

Schiestl, F.P. \& S. Dötterl. 2012. The evolution of floral scent and olfactory preferences in pollinators: coevolution or pre-existing bias? Evolution 66: 2042-2055.

Soto Arenas, M.A., R. Solano Gómez \& E. Hágsater. 2007. Risk of extinction and patterns of diversity loss in Mexican orchids. Lankesteriana 7: 114-121.

Stebbins, G.L. 1984. Mosaic evolution, mosaic selection and angiosperm phylogeny. Bot. J. Linn. Soc. 88: 159164.

Thompson, J., N. Brokaw, J.K. Zimmerman, R.B. Waide,
E.M. III, Everham, D.J. Lodge, C.M. Taylor, D. García-Montiel \& M. Fluet. 2002. Land use history, environment, and tree composition in a tropical forest. Ecol. Appl. 12: 1344-1363.

Thornton, I.W.B. 1997. Krakatau: the destruction and reassembly of an island ecosystem. Harvard University Press, Cambridge, Massachusetts.

Tremblay, R.L., J.D. Ackerman, J.K. Zimmerman \& R.N. Calvo. 2005. Variation in sexual reproduction in orchids and its evolutionary consequences: a spasmodic journey to diversification. Biol. J. Linn. Soc. 84: 1-54.

Tremblay, R.L., E. Meléndez-Ackerman \& D. Kapan. 2006. Do epiphytic orchids behave as metapopulations? Evidence from colonization, extinction rates and asynchronous population dynamics. Biol. Conserv. 129: 70-81.

van der Pijl, L. \& C.H. Dodson. 1966. Orchid flowers: their pollination and evolution. University of Miami Press, Coral Gables.

Wadsworth, F.H. 1950. Notes on the climax forest of Puerto Rico and their destruction and conservation prior to 1900. Caribb. Forester 11: 48-47. 